\title{
On the uncertainty beneath the name Oithona similis Claus, 1866 (Copepoda, Cyclopoida)
}

\author{
Georgina D. Cepeda ${ }^{1,2}$, Marina E. Sabatini ${ }^{1,2}$, Cristina L. Scioscia ${ }^{3}$, \\ Fernando C. Ramírez², María D. Viñas ${ }^{1,2}$ \\ I Instituto de Investigaciones Marinas y Costeras (IIMyC), Facultad de Ciencias Exactas y Naturales, Universidad \\ Nacional de Mar del Plata, Consejo Nacional de Investigaciones Cientificas y Técnicas (CONICET), Funes \\ 3350, B7602AYL Mar del Plata, Argentina 2 Instituto Nacional de Investigación y Desarrollo Pesquero \\ (INIDEP), Paseo Victoria Ocampo No 1, B7602HSA Mar del Plata, Argentina 3 Museo Argentino de Ciencias \\ Naturales Bernardino Rivadavia (CONICET-MACNBR), Avenida Ángel Gallardo 470, C1405DJR Buenos \\ Aires, Argentina
}

Corresponding author: Georgina D. Cepeda (gcepeda@inidep.edu.ar)

Academic editor: D. Defaye | Received 12 June 2015 | Accepted 16 September 2015 | Published 13 January 2016

http://zoobank.org/3BB463B7-248A-4D86-8405-4FA008F9CA8B

Citation: Cepeda GD, Sabatini ME, Scioscia CL, Ramírez FC, Viñas MD (2016) On the uncertainty beneath the name Oithona similis Claus, 1866 (Copepoda, Cyclopoida). ZooKeys 552: 1-15. doi: 10.3897/zookeys.552.6083

\begin{abstract}
The marine cyclopoid Oithona similis sensu lato Claus, 1866, is considered to be one of the most abundant and ubiquitous copepods in the world. However, its minimal original diagnosis and the unclear connection with its (subjective) senior synonym Oithona helgolandica Claus, 1863, may have caused frequent misidentification of the species. Consequently, it seems possible that several closely related but distinct forms are being named $O$. similis or $O$. helgolandica without explicit and accurate discrimination. Here the current situation concerning the correct assignment of the two species is revised, the morphological characters commonly used to identify and distinguish each species are summarized, and the nomenclatural implications of indiscriminately using these names in current taxonomic and ecological practice is considered. It is not intended to upset a long-accepted name in its accustomed meaning but certainly the opposite. "In pursuit of the maximum stability compatible with taxonomic freedom" (International Commission of Zoological Nomenclature), we consider that reassessment of the diagnostic characters of $O$. similis sensu stricto cannot be postponed much longer. While a consensus on taxonomy and nomenclatural matters can be attained, we strongly recommend specifically reporting the authority upon which the identification of either $O$. similis s.l. or $O$. helgolandica s.l. has been accomplished.
\end{abstract}

Copyright Georgina D. Cepeda et al. This is an open access article distributed under the terms of the Creative Commons Attribution License (CC BY 4.0), which permits unrestricted use, distribution, and reproduction in any medium, provided the original author and source are credited. 


\section{Keywords}

Nomenclature, Oithona helgolandica Claus, 1863, Oithona similis Claus, 1866, sequence databases, taxonomy

\section{Introduction}

A global-scale baseline assessment of marine zooplankton biodiversity is critically needed to provide a contemporary benchmark against which future environmental changes can be evaluated (Bucklin et al. 2011). The largest obstacle for most zooplankton taxa is the difficulty in identifying specimens, which has resulted in marked underspecification of species and morphological types. The small cyclopoid Oithona similis Claus, 1866 is recognized as one of the most important marine copepods in terms of both abundance and breadth of distribution, occupying a key position in the global oceans (Galliene and Robins 2001). However, there is still much confusion regarding not only characters for its recognition but also its name.

Oithona similis was first described by Claus in 1866 from specimens collected in the Mediterranean Sea, near Nice, France. Three years earlier, the same author had described a very similar congener from waters off Helgoland (North Sea) that he named $O$. helgolandica (Claus 1863). The original description of the two species were too brief, unfortunately, to allow for adequate discrimination of the two species, and the synonymy between them has been under discussion ever since.

In our opinion, a rather confusing subjective synonymy of the two names has developed in recent practice, and the junior name similis has been imposed over helgolandica by prevailing usage, which is in clear contravention of the Principle of Priority (International Commission on Zoological Nomenclature, hereafter ICZN 1999, Article 23). Both specific names have coexisted since 1866, and both are currently in use depending upon authors' taxonomic judgment. In our own experience, the replacement of the name $O$. helgolandica by $O$. similis has very often been requested by reviewers located worldwide, even when there is the possibility that the two names may refer to two distinctive taxa.

Among contemporary records, references to $O$. similis are plentiful from almost everywhere in the world's oceans (Razouls et al. 2005-2015), while references to $O$. helgolandica appear to be restricted to relatively few regions: NW and N Iberian shelf (e.g., Cabal et al. 2008), Gulf of Lion (e.g., Razouls 1972), Ligurean Sea (e.g., Pane et al. 2005), Tyrrhenian and Ionian seas (e.g., Vaissiere and Seguin 1980), SW Mediterranean Sea and Atlantic coast of Morocco (e.g., Hafferssas and Seridji 2010) and Red Sea (e.g., Vaissiere and Seguin 1980). In the SW Atlantic both names have been recorded: Oithona similis has been used by, for example, Pallares (1968), Björnberg (1981), Mazzochi et al. (1995), Viñas et al. (2002), Fernández-Severini and Hoffmeyer (2005), Aguirre et al. (2012), Cepeda et al. (2012), Thompson et al. (2012), and $O$. helgolandica by, for example, Ramírez (1970), Sabatini and Martos (2002), Viñas et al. (2013), Antacli et al. (2014), and Temperoni et al. (2014). 
New approaches such as molecular tools are becoming increasingly attractive for identifying plankton. Advancements, however, depend largely on the provision of reference libraries with sequences coming from accurately identified individuals (Lindeque et al. 2013). There is the urgent need to clarify these issues, so both morphological and metagenetic global databases can be refined before upcoming studies enhance the current confusion. Rather than trying to prove a point, we review here the historical debate going back to the assignment of the two specific names, summarize the arguments that give support to the hypothesis that $O$. similis and $O$. helgolandica are not truly objective synonyms and discuss the implications of using both names in present times without exacting discrimination. "In pursuit of the maximum stability compatible with taxonomic freedom" (ICZN 1999; Principle \#4), we consider that reassessment of the diagnostic characters of $O$. similis s.s. and $O$. helgolandica s.s. cannot be postponed.

\section{Historical background}

Original diagnoses of $O$. helgolandica and $O$. similis were in both cases brief and mainly based on the comparison with a third species, O. spinirostris Claus, $1863(=O$. plumifera Baird, 1843). Actually, the first description of the older species $O$. helgolandica makes real sense only when simultaneously looking at drawings by the same author of female O. spinirostris from Messina (Italy) (Claus 1863: Plate XI, figs 4-9). Only the male abdomen, antenna and antennule of $O$. helgolandica were figured by Claus in the same plate (Plate XI, figs 10-12). Regarding $O$. similis, Claus's first characterization from specimens collected off Nice was even less complete, and no drawings were provided. Unfortunately, Claus never wrote a comparison of the two species and, to our knowledge, he never deposited any type material for either in a museum.

When studying the copepod fauna from Naples, Giesbrecht (1893) realized that the species $O$. spinirostris described by Claus from Messina and Nice, as well as the one that he was himself recording from waters off Naples at that moment, were actually identical to O. plumifera Baird, 1843, although different from the Kiel specimens he had erroneously identified earlier as O. spinirostris (Giesbrecht 1881).

Giesbrecht (1893) identified another small form from Naples that he had recorded before as $O$. similis Claus off southern Chile and in the Indian Ocean (Giesbrecht $1891 \mathrm{a}, 1891 \mathrm{~b})$. Only then did he notice the close resemblance between the $O$. similis specimens from Naples and those collected earlier at Kiel. In fact, only the antennule length prevented him from considering both forms to be identical to O. helgolandica Claus (Giesbrecht 1893: 539). He described and figured the adult female and male of Neapolitan specimens, thus offering the first detailed description of $O$. similis and a comparison with all other congeners recognized at the time. It is worth highlighting that Giesbrecht also commented extensively on the identity and synonymy between $O$. similis from Naples and Kiel and $O$. helgolandica from Helgoland. Being unable to 
conclude, he expressed his doubts with question marks when listing synonyms of $O$. similis Claus (Giesbrecht 1893 : 537) and suggested the possibility that the majority of the species recorded in the North Atlantic would be (literally) "O. helgolandica Claus = ? spinirostris Giesbrecht, $1881=O$. similis Claus". As this reads, he gave priority to $O$. helgolandica over $O$. similis.

Overlooking Giesbrecht's hesitation and without any factual justification for his judgment, Farran (1913) accepted $O$. similis as a good species and excluded $O$. helgolandica (and all other synonyms suggested to that date) from his key for the identification of Oithona and Paroithona. All known species at the time were therein listed and classified based upon the presence/absence of a rostrum and the external exopod setation of the swimming legs. Farran's deliberate omission of $O$. helgolandica and his oversimplification of characters for the classification of Oithona species probably have been applied many times until the present day.

In the same year, Sars (1913) recorded the form occurring abundantly in the fjords and offshore waters of Norway as $O$. helgolandica. In his opinion, $O$. helgolandica was unmistakably identical with $O$. similis. Sars stated then that the former name should be retained in accord with the rules of priority. He extended this synonymy to the doubtful species from Kiel that Giesbrecht (1881) had initially identified as O. spinirostris. It may turn out to be non-trivial that the specimens from New Zealand, also examined by Sars (1913), showed no apparent difference from the northern species. In line with Sars, Scott (1914) also alluded to O. helgolandica in referring to animals collected off Argentina near to the Malvinas Islands in the SW Atlantic.

In contrast, Rosendorn (1917) named the form he had collected off Chile as $O$. similis, although in this case after Giesbrecht's (1893) description which was based on Neapolitan specimens. While Chilean males fit the description of Mediterranean specimens well, the females differed slightly in the exopod setation of legs 1 and 4 . In Rosendorn's own words, "Giesbrecht probably overlooked the distal outer spine on the third segment of leg 4, as well as one inner seta on the third segment of leg 1 " (Rosendorn 1917: 24) (Table 1).

In a surprising twist, Sars (1918) radically changed his former opinion and, "on a closer consideration," he concluded that "the two forms recorded by Claus under the names $O$. helgolandica and $O$. similis are in reality very distinct species, the former being in all probability identical with the form subsequently described by Giesbrecht as $O$. nana, which accordingly must bear the older name helgolandica." For the Norwegian form "the specific name similis given by Claus ought of course to be retained" (Sars 1918: 207).

More recently, Crisafi (1959) reviewed the historical sequence and concluded that $O$. similis should be regarded as synonymous with $O$. helgolandica on the grounds that the singular characters for the junior name, O. similis, in Claus's diagnosis were insufficient to establish a new species. Nishida et al. (1977: 151) also discussed the issue but suggested, on the contrary, that the name helgolandica "should be rejected because of uncertainty and that Giesbrecht's (1893) description of $O$. similis is accepted as a good species". As did Crisafi (1959), we believe that Claus was unable to find the set 


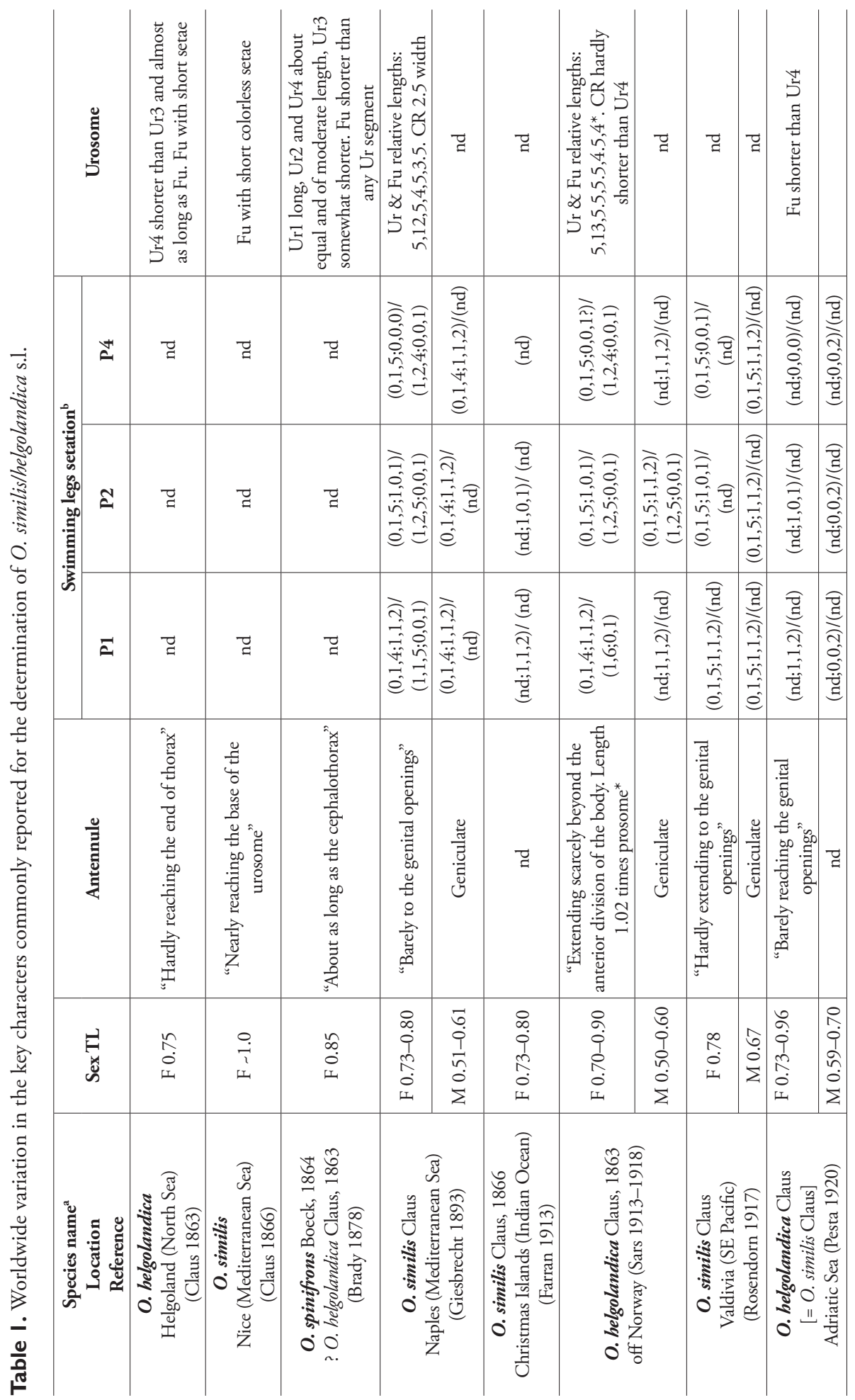




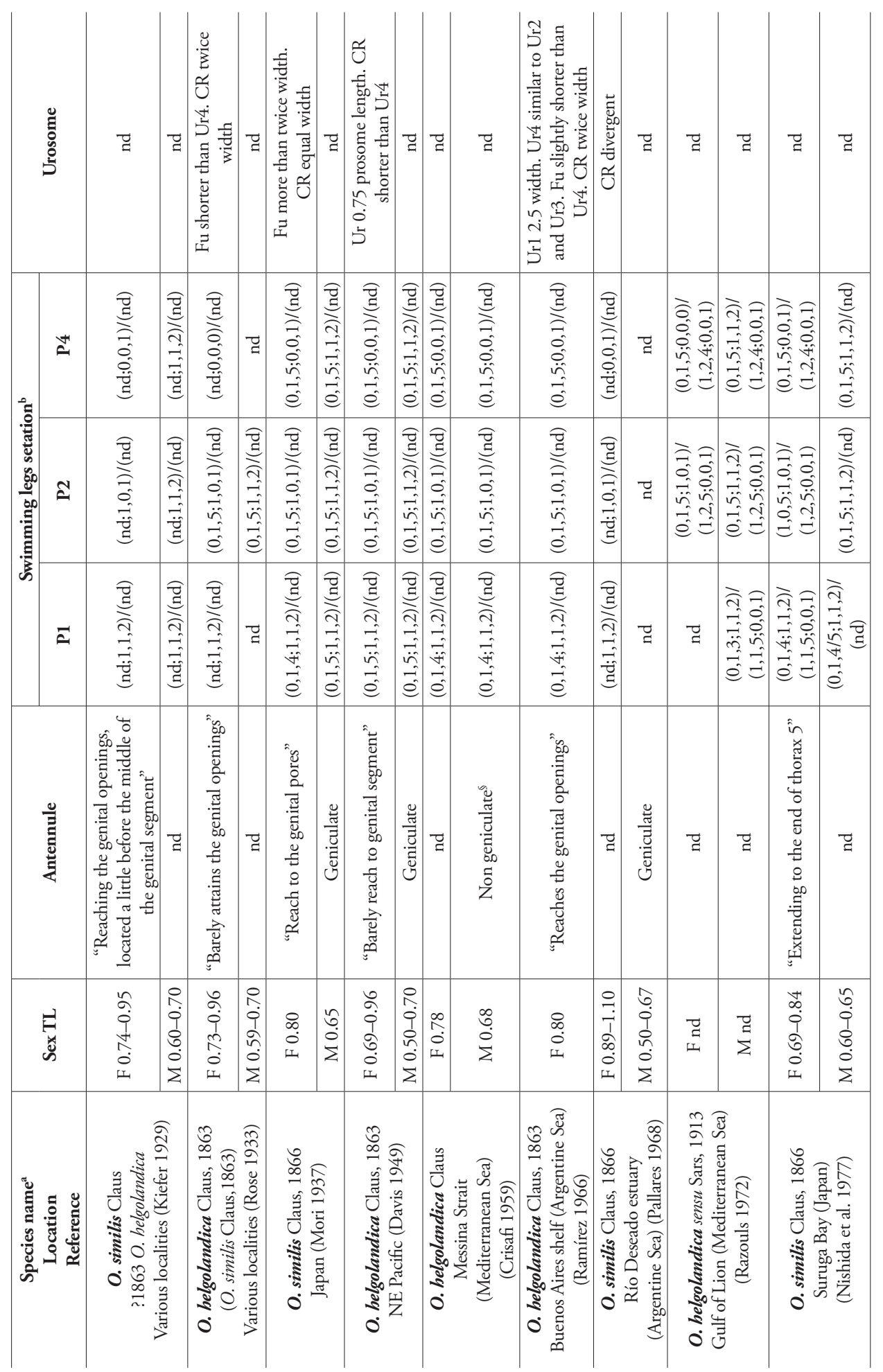




\begin{tabular}{|c|c|c|c|c|c|c|c|}
\hline 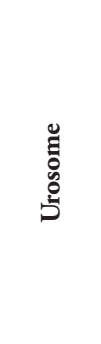 & $\vec{z}$ & $\overrightarrow{\vec{F}}$ & $\overrightarrow{\vec{F}} \mid \overrightarrow{\vec{F}}$ & 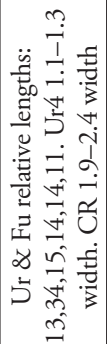 & 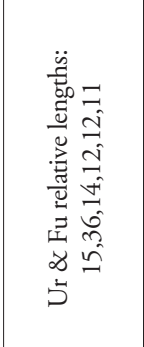 & 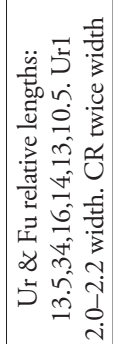 & $\vec{z}$ \\
\hline$\Xi^{ \pm t}$ & 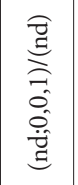 & $\vec{z}$ & 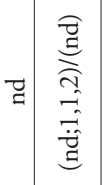 & 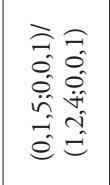 & 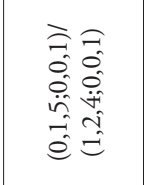 & 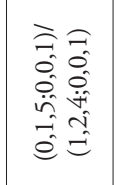 & 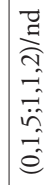 \\
\hline 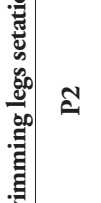 & 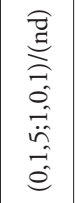 & $\vec{z}$ & 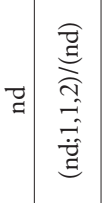 & 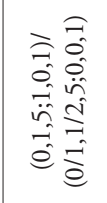 & 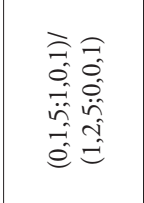 & $\begin{array}{ll}\hat{=} & = \\
0 & 0 \\
\overrightarrow{0} & 0 \\
\hat{n} & \hat{n} \\
\overrightarrow{0} & =\end{array}$ & 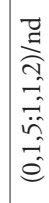 \\
\hline $\bar{\Xi}$ & 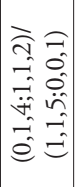 & $\vec{z}$ & 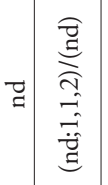 & 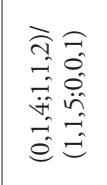 & 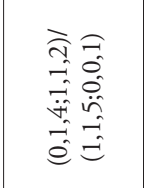 & 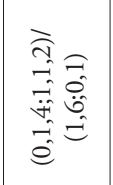 & 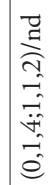 \\
\hline 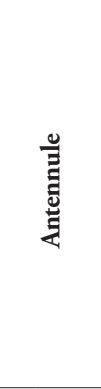 & $\vec{Z}$ & $\vec{z}$ & 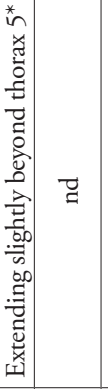 & 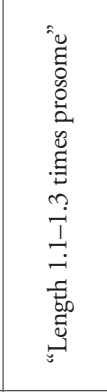 & $\vec{q}$ & 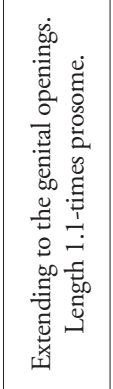 & 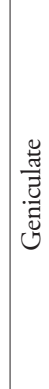 \\
\hline 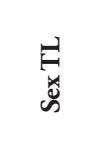 & \begin{tabular}{l}
$\infty$ \\
$\stackrel{\infty}{0}$ \\
\multirow{1}{4}{}
\end{tabular} & $\mid \begin{array}{c}0 \\
0 \\
0 \\
1 \\
0 \\
0 \\
0 \\
\Sigma \\
\Sigma\end{array}$ & 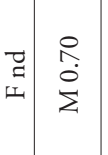 & 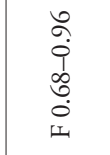 & 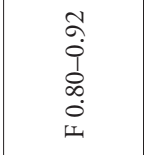 & 工 & $\Sigma$ \\
\hline 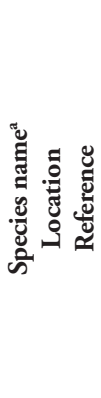 & 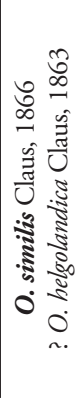 & 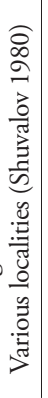 & 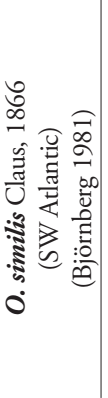 & 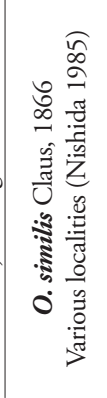 & 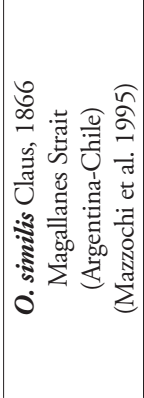 & \multicolumn{2}{|c|}{ 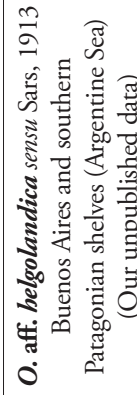 } \\
\hline
\end{tabular}


of differential characters that would have been necessary for the proposal of a new species. He probably described under the new name similis individuals that were similar, though not identical, to the species he found formerly in Helgoland.

Given this state of the problem, many authors have subsequently either applied the Principle of Priority or followed Crisafi's (1959) opinion, naming the species $O$. helgolandica (e.g., Pesta 1920; Rose 1933; Davis 1949; Crisafi 1959; Ramírez 1966, 1970; Razouls 1972; Huys and Boxshall 1991). Many others have preferred to refer to O. similis (e.g., Farran 1929; Kiefer 1929; Mori 1937; Rose 1957; Nishida et al. 1977; Shuvalov 1980; Nishida 1985), although some of those indicated with question marks their doubts about synonymy with the senior form $O$. helgolandica. This ambiguity has continued until the present day.

\section{Do the names O. similis and O. helgolandica refer to identical taxa?}

Most important morphological features usually used for the identification of $O$. similis / helgolandica s.l. have been: (i) body size, (ii) rostrum presence and direction, (iii) relative antennule length, (iv) exopod setation of swimming legs 1-4, and (v) relative lengths of the genital segment, anal segment, and furcae.

Morphological differences among specimens worldwide (Table 1; Fig. 1) suggest that at least two forms may be referred to O. similis / helgolandica s.l. Strict comparisons across records are not really possible, because they all lack the detail of one or more particular key characters; hence, it seems likely that identification of $O$. similis s.l. I helgolandica s.l. has generally been based on elements insufficient for adequate taxonomic judgment. This is not minor when considering that phenetically similar species may differ from one another in only slight differences of the setal formula of the swimming legs (Nishida 1985). We are calling attention here to the fact that the female and male exopod setation of swimming legs do not match identically in the two most complete and detailed redescriptions of $O$. similis by Giesbrecht (1893) and Nishida (1985), and neither is there complete correlation between Nishida et al (1977) and Nishida (1985) (Table 1).

Some subtle differences are apparent among published drawings labelled as $O$. similis s.l. and of $O$. helgolandica s.l. (Fig. 1). In this regard, it may be worth examining closely the drawings of female $O$. helgolandica by Sars (1913, Plate III) and $O$. spinifrons Boeck, 1864 (= ? O. helgolandica Claus) by Brady (1878, Plates XIV and XXIV A). In considering $O$. similis as figured by Nishida (1985), note in particular the dissimilar general appearance with respect to the above mentioned species, the two-segmented endopod of the first leg, and the overall setation of legs 1-4 (on the inner and outer borders of both rami). Nishida's descriptions and drawings probably correspond to the "typical" $O$. similis, on which a substantial number of authors have based identifications since 1985 .

In our view, when specimens have been identified as $O$. similis s.l., insufficient attention has often been paid to: (i) presence/absence of the small distal outer spine 


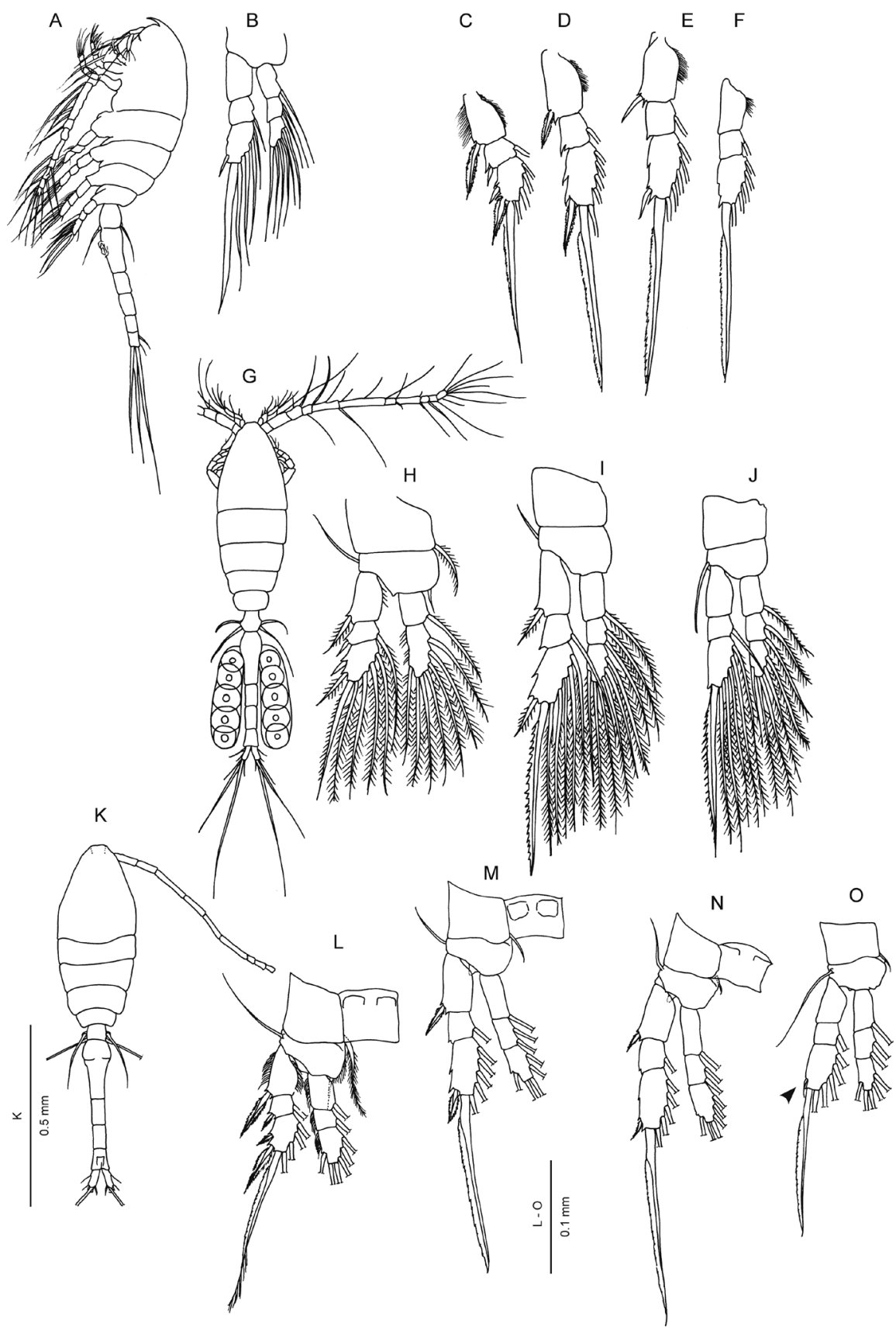

Figure I. Former selected drawings of $O$. similis / helgolandica. A, B O. spinifrons Boeck, 1864 (=? O. helgolandica Claus), female body and "one of swimming feet" (= leg 4?) (after Brady1878, Plates XIV and XXIV A) C-F O. similis exopod of legs 1 to 4 (after Gisbrecht 1893, Plate 34) G-J O. helgolandica, female body, legs 1-2 and leg 4 (after Sars 1913, Plate III) K-O O. similis, female body and legs 1 to 4 (after Nishida 1985, fig. 50 and 51). Original illustrations were faithfully copied in all details and rearranged to facilitate comparisons. Scale bars only provided in Nishida (1985). 
on exopod segment 3 of leg 4, (ii) endopod segmentation of leg 1, and (iii) relative antennule length.

The distal outer spine on the last segment of the exopod of leg 4 is lacking in some early descriptions and drawings of O. similis / helgolandica (e.g., Giesbrecht 1893; Pesta 1920; Rose 1933). Sars (1913) gives account of it in the text (p. 8) but it is unclear in his drawing. According to Farran (1913) and Crisafi (1959), this spine can be easily lost, although it may also have been overlooked, as Rosendorn (1917) suggested. From records in the literature, doubt remains whether or not all Mediterranean specimens share this particular character, the presence of this spine (Table 1).

In the genus Oithona Baird, both rami of the first swimming leg are 3-segmented (sensu Brady 1878), but this is not always the case in O. similis s.l. and O. helgolandica s.l. To our knowledge, a bi-segmented endopod of leg 1 has only been specifically reported so far for female Oithona specimens from Norway (Sars 1913), the Gulf of Lion (Razouls 1972), and off Argentina (our unpublished data). Like most authors listed in Table 1, Giesbrecht (1893) only figured the outer rami of the swimming legs, though he addressed secondarily his observation that "segments 2 and 3 of the endopod were often indistinctly separated in the front pairs of O. similis" (on p. 544).

Lastly, the antennule length relative to the prosome appears slightly variable across records worldwide (Table 1). Because this feature has been most often characterized in a subjective way, it is suggested that it be reported quantitatively in the future (e.g., antennule length 1.1-1.3 times prosome length, as reported by Nishida 1985).

From the genetic point of view, the still scarce molecular studies on Oithona also support the hypothesis that more than one form is reported under the same specific name, O. similis s.l. Cepeda et al. (2012) presented data showing significant genetic differentiation among numerous and widespread locations in the North and South Atlantic Ocean based on $28 \mathrm{~S}$ rDNA, suggesting some degree of isolation amongst sampled populations. Furthermore, preliminary findings from cytochrome c oxidase I (COI) "barcode" analyses of (apparently) morphologically identical $O$. similis over a broad geographical scale, i.e. Arctic and Southern oceans, North Sea and Mediterranean Sea, revealed the presence of several different haplotypes restricted to particular areas (Wend-Heckmann 2013). There is thus the possibility that $O$. similis s.l. is not a single, broadly distributed, cosmopolitan species but rather, a conglomerate of several cryptic species. This has been the case of many putatively cosmopolitan species (Bucklin et al. 2011). In this regard, markers frequently used to investigate boundary taxa among closely related, cryptic and cosmopolitan species may be helpful (e.g., COI, cytochrome b, 16S rRNA, Internal Transcribed Spacer 1-2).

\section{Nomenclatural remarks and perspectives}

The nomenclatural implications of the taxonomic uncertainty apparent from the discussions above are not minor. From a historical standpoint, it is clear that over the course of time a substantial number of copepodologists has come to consider that $O$. 
similis and $O$. helgolandica actually denote the same taxon. Prevailing use which, as shown, has depended upon individual judgment and opinion, has made that the junior synonym $O$. similis were very commonly imposed over the older $O$. helgolandica, contradicting the rules of priority (ICZN 1999; Article 23).

On the other hand, morphological differences worldwide in the key characters commonly used for diagnosis (Table 1 ) suggest that $O$. similis and $O$. helgolandica may not refer to copepods related closely enough to be considered a single taxon. Because the problem focuses on the identity of Claus's types, which unfortunately are not available, we advocate a thorough comparison of the two taxonomic entities, preferably at both the morphological and genetic levels (McManus and Katz 2009), from specimens newly collected at their respective type localities, i.e, Nice and Helgoland.

In the absence of proper holotypes, the designation of neotypes probably will be required because of the points raised above (ICZN 1999; Article. 75), i.e.:

(i) A neotype each for O. helgolandica s.s. Claus, 1863 and for O. similis s.s. Claus, 1866 will be needed if specimens from both localities are proved to be different.

(ii) The appointment of only one neotype will be necessary if specimens from Nice and Helgoland are substantially identical. Strictly speaking, in this situation the senior name $O$. helgolandica should be used because of the rules of priority. Nevertheless, in pursuit of stability and universality and to avoid causing further confusion, it would be still possible to maintain the use of the junior synonym, O. similis, as it has largely prevailed through time. To stabilise this, however, the matter must be referred to the ICZN for a ruling under the plenary powers (ICZN 1999; Article 23.9.3).

There are not, in fact, conclusive fundamentals at present in support of an objective synonymy between the names $O$. similis and $O$. helgolandica. Hence, until the diagnostic characters are re-examined and the nomenclatural issues settled, we strongly recommend specifically reporting the authority upon which the identification of either $O$. similis s.l. or $O$. helgolandica s.l. has been undertaken. In this process, particular reference should be made for female specimens in respect to: (i) relative antennule length, (ii) presence/absence of the small distal outer spine on exopod segment 3 of leg 4, and (iii) endopod segmentation of leg 1.

After this review, we find astounding the extent of taxonomic and nomenclatural uncertainty surrounding the name $O$. similis. Poor original diagnosis and frequently the inability of authors to perceive minute morphological differences have very likely caused the assembly of several forms distinct at the species level into a single, nominal species. This circumstance on top of the persistent confusion with its likely sibling, $O$. helgolandica, may have led to a false impression of cosmopolitanism. It is possible that many cryptic species are veiled behind the apparent morphological homogeneity of their forms, and $O$. similis s.l. and $O$. helgolandica s.l. may be an example in an abundant and ecologically important group, the genus Oithona. Therefore, we encourage a profound revision of $O$. similis s.l. in order to bring the exact status of this species to light. In accomplishing this goal, species should not be renamed or newly assigned based on morphology alone without the support of molecular genetic sequence information. 


\section{Acknowledgements}

The authors are grateful to Martin Ehrlich, Norberto Scarlato, and Katharina Faulhaber for kindly translating sections of Claus (1863, 1866), Giesbrecht (1881, 1891a,b, 1893), Rosendorn (1917) and other German classics into English. We specially thank INIDEP librarians for making available the old books and documents with former descriptions.

Paula Israilson helped prepare illustrations for publication. Comments and stimulus by Silvina Menú Marque, Ann Bucklin, and Charlie Miller on an early version of the manuscript are most appreciated. We thank two reviewers for their opinions and valuable suggestions which improved the manuscript. This is INIDEP contribution No. 1943.

\section{References}

Aguirre G, Capitanio F, Lovrich G, Esnal G (2012) Seasonal variability of metazooplankton in coastal sub-Antarctic waters (Beagle Channel). Marine Biology Research 8: 318-300. doi: $10.1080 / 17451000.2011 .627922$

Antacli J, Hernández D, Sabatini M (2014) First report on the contribution of small-sized species to the copepod community structure of the southern Patagonian shelf (Argentina, $47^{\circ}-55^{\circ}$ S). Scientia Marina 78: 17-26. doi: 10.3989/scimar.03906.31C

Baird W (1843) Notes on British Entomostraca. Zoologist 1: 55-61.

Björnberg T (1981) Copepoda. In: Boltovskoy D (Ed.) Atlas del Zooplancton del Atlántico Sudoccidental y Métodos de Trabajo con el Zooplancton Marino. Publicaciones Especiales INIDEP, Mar del Plata, 587-679.

Boeck A (1864) Oversigt over de ved Norges Kyster jagttagne Copepoder, henhörende til Calanidernes, Cyclopidernes og Harpactidernes Familier. Forhandlinger i Videnskabs-Selskabet i Christiania, 1864: 226-282.

Brady G (1878) A monograph of the free and semi-parasitic Copepoda of the British Islands. Ray Society, London. doi: 10.5962/bhl.title.58691

Bucklin A, Steinke D, Blanco-Bercial L (2011) DNA Barcoding of Marine Metazoa. The Annual Review of Marine Science 3: 471-508. doi: 10.1146/annurev-marine-120308-080950

Cabal J, González-Nuevo G, Nogueira E (2008) Mesozooplankton species distribution in the NW and N Iberian shelf during spring 2004: Relationship with frontal structures. Journal of Marine Systems 72: 282-297. doi: 10.1016/j.jmarsys.2007.05.013

Cepeda G, Blanco-Bercial L, Bucklin A, Berón C, Viñas MD (2012) Molecular systematics of three species of Oithona (Copepoda, Cyclopoida) from the Atlantic Ocean: comparative analysis using 28S rDNA. PLoS ONE 7: e35861. doi: 10.1371/journal.pone.0035861

Claus C (1863) Die freilebenden Copepoden mit besonderer Berücksichtigung der Fauna Deutslands, der Nordsee und des Mittelmeeres. Verlag von Wilhelm Engelmann, Leipzig. Claus C (1866) Die Copepoden-Fauna von Nice. Ein Beitrag zur Charakteristik 299 der Formen und deren Abänderungen “im Sinne Darwin's”. Schriften der Gesellschaft zur Beförderung der Gesamten Naturwissenschaften zu Marburg, Supplement 1: 1-34. 
Crisafi P (1959) Sulla Oithona helgolandica Claus (Copepoda, Cyclopoida) dello stretto di Messina. Bollettino di Zoologia 26: 49-57. doi: 10.1080/11250005909438304

Davis C (1949) The pelagic Copepoda of the northeastern Pacific Ocean. University of Washington Publications in Biology.

Farran G (1913) Plankton from Christmas Island, Indian Ocean. II. On Copepoda of the genera Oithona and Paroithona. Proceedings of the Zoological Society of London 1913: 181-193.

Farran G (1929) Crustacea - Part X - Copepoda Natural History Reports of the British Museum, British Antarctic ('Terra Nova') Expedition. Zoology 8: 203-306.

Fernández-Severini M, Hoffmeyer M (2005) Mesozooplankton assemblages in two bays in the Beagle Channel (Argentina) during January 2001. Scientia Marina 69: 27-37.

Gallienne C, Robins D (2001) Is Oithona the most important copepod in the world's oceans? Journal of Plankton Research 23: 1421-1432. doi: 10.1093/plankt/23.12.1421

Giesbrecht W (1881) Vorläufige Mitteilung aus einer über die freilebenden Copepoden der Kieler Hafens. Zoologischer Anzeiger 4: 254-258.

Giesbrecht W (1891a) Elenco dei Copepodi pelagici raccolti dal Tenete di vascello Gaetano Chierchia durante il viaggio della R. Corvetta "Vettor Pisani" negli anni 1882-1885 e dal Tenente di vascello Francesco Orsini nel Mar Rosso, nel 1884. Atti della Academia Nazionale dei Lincei. Classe di Science Fisiche, Matematiche e Naturali. Serie IX. Rendiconti Lincei Scienze Fisiche e Naturali 7: 474-481.

Giesbrecht W (1891b) Elenco dei Copepodi pescati dalla R. Corvetta "Vettor Pisani” secondo la loro distribuzione geografica. Atti della Academia Nazionale dei Lincei, Classe di Science Fisiche, Matematiche e Naturali 7: 276-282.

Giesbrecht W (1893 [“1892”]) Systematik und Faunistik der pelagischen Copepoden des 297 und der angrenzenden Meeres-Abschnitte. Fauna und Flore des Golfes von Neapel und der angrenzenden Meeres-Abschitte. Monographie 19: 1-831.

Hafferssas A, Seridji R (2010) Relationships between the hydrodynamics and changes in copepod structure on the Algerian coast. Zoological Studies 49: 353-366.

Huys R, Boxshall GA (1991) Copepod Evolution. The Ray Society, clo The Natural History Museum, Cromwell Road, London.

International Commission on Zoological Nomenclature (1999) International Code of Zoological Nomenclature. Fourth edition. The International Trust for Zoological Nomenclature 1999, c/o The Natural History Museum, London.

Kiefer F (1929) Crustacea Copepoda. II. Cyclopoida Gnathostoma. Das Tierreich 53: 1-102.

Lindeque P, Parry H, Harmer R, Somerfield P, Atkinson A (2013) Next generation sequencing reveals the hidden diversity of zooplankton assemblages. PLoS ONE 8: e81327. doi: 10.1371/journal.pone.0081327

McManus G, Katz L (2009) Molecular and morphological methods for identifying plankton: what makes a successful marriage? Journal of Plankton Research 3: 1119-1129. doi: 10.1093/plankt/fbp061

Mazzochi M, Zagani G, Ianora A, Guglielmo L, Crescenti N, Hure J (1995) Copepods. In: Guglielmo L, Ianora A (Eds) Atlas of Marine Zooplankton, Straits of Magellan. SpringerVerlag, Berlin, Heidelberg, New York. doi: 10.1007/978-3-642-79139-0 
Mori T (1937) The pelagic copepoda from the neighbouring waters of Japan. Yokendo Company, Tokyo, $150 \mathrm{pp}$.

Nishida S, Tanaka O, Omori M (1977) Cyclopoid copepods of the family Oithonidae in Suruga Bay and adjacent waters. Bulletin of the Plankton Society of Japan 24: 119-158. doi: $10.1246 /$ bcsj. 50.119

Nishida S (1985) Taxonomy and distribution of the family Oithonidae (Copepoda: Cyclopoida) in the Pacific and Indian Oceans. Bulletin Ocean Research Institute University of Tokyo 20: 1-167.

Pallares R (1968) Copépodos marinos de la Ría Deseado (Santa Cruz, Argentina). Servicio de Hidrografía Naval, SHN Serie Pública 1024, Buenos Aires.

Pane L, Boccardo S, Mariottini G (2005) Mesozooplankton assemblage and first record of Paracartia grani Sars G.O., 1904 (Copepoda: Calanoida) in the western harbour of Genova (Ligurian Sea). Rivista di Biologia/Biology Forum 98: 323-336.

Pesta O (1920) Die Planktoncopepoden der Adria. Zoologische Jahrbücher, Abteilung für Systematik, Geographie und Biologie der Tiere 43: 471-660.

Ramírez F (1966) Copépodos ciclopoideos y harpacticoideos del plancton de Mar del Plata. Physis 26: 285-292.

Ramírez F (1970) Copépodos planctónicos del sector bonaerense del Atlántico Sudoccidental. Datos y resultados de las campańas Pesquería. Contribuciones Instituto Biología Marina 98: $1-116$.

Razouls C (1972) Estimation de la production secondaire (copépodes pélagiques) dans une province néritique méditerranéenne (Golfe du Lion). Tome Annexe, fig. 61-62. Thèse Doctorat Etat Sciences, Université Pierre et Marie Curie, Paris. Available from: http:// copepodes.obs-banyuls.fr/en/ [accessed 25 February 2015]

Razouls C, de Bovée F, Kouwenberg J, Desreumaux N (2005-2015) Diversity and Geographic Distribution of Marine Planktonic Copepods. http://copepodes.obs-banyuls.fr/en/ [accessed 25 February 2015]

Rose M (1933) Copépodes pélagiques. In Faune de France 26, Paris, 374 pp.

Rose M (1957) Les Crustacés. In: Trégouboff G, Rose M (Eds) Manuel de Planctonologie Méditerranéenne. Centre National de la Recherche Scientifique, Paris, 431-465.

Rosendorn L (1917) Die Gattung Oithona. Wissenschaftliche Ergebnisse der Deutschen TiefseeExpedition 'Valdivia' 1898-1899, 23-58.

Sabatini M, Martos P (2002) Mesozooplankton features in a frontal area off northern Patagonia (Argentina) during spring 1995 and 1998. Scientia Marina 66: 215-232.

Sars G (1913-1918) An account of the Crustacea of Norway with short descriptions and figures of all the species. Copepoda Cyclopoida. Vol. VI. Bergen Museum, 225 pp., Pls I-XVIII. (Instalment selling: 1913: 1-56, Pls 1-32; 1914: 57-104, Pls 33-48; 1915: 105-140, Pls 49-80; 1917: 141-172 Pls 81-96; 1918: 173-225, Pls 97-118).

Scott T (1914) Remarks on some Copepoda from the Falkland Islands collected by Mr. Rupert Vallentin, F.L.S. Annals and Magazine of Natural History 8: 1-11. doi: $10.1080 / 00222931408693449$

Shuvalov V (1980) Copepoda crustaceans - Cyclopoida of the family Oithonidae of the world oceans. Nauka Press, Leningrad. 
Temperoni B, Vińas MD, Martos P, Marrari M (2014) Spatial patterns of copepod biodiversity in relation to a tidal front system in the main spawning and nursery area of the Argentine hake Merluccius hubbsi. Journal of Marine Systems 139: 433-445. doi: 10.1016/j. jmarsys.2014.08.015

Thompson G, Dinofrio E, Alder V (2012) Interannual fluctuations in copepod abundance and contribution of small forms in the Drake Passage during austral summer. Helgoland Marine Research 66: 127-138. doi: 10.1007/s10152-011-0253-4

Vaissiere R, Seguin G (1980) Etude preliminaire de peuplements copepodes (juillet 1977) en relation avec l'hydrologie des mers Tyrrhenienne et Ionienne. Oceanologica Acta 3: 17-29.

Viñas M, Negri R, Ramírez F, Hernández D (2002) Zooplankton assemblages and hydrography in the spawning area of anchovy (Engraulis anchoita) off Río de la Plata estuary (Argentina-Uruguay). Marine and Freshwater Research 53: 1031-1043. doi: 10.1071/MF00105

Viñas M, Negri R, Cepeda G, Hernández D, Silva R, Daponte M, Capitanio F (2013) Seasonal succession of zooplankton in coastal waters of the Argentine Sea (Southwest Atlantic Ocean): prevalence of classical or microbial food webs. Marine Biology Research 9: 371-382. doi: $10.1080 / 17451000.2012 .745003$

Wend-Heckmann B (2013) Oithona similis (Copepoda: Cyclopoida) -a cosmopolitan species? Zur Erlangung des akademischen Grades eines Doktors der Naturwissenschaften Doktor der Naturwissenschaften durch die Fachbereiche Biologie/Chemie der Universität Bremen. http://elib.suub.uni-bremen.de/edocs/00103163-1.pdf/ [accessed 20 February 2015] 